\title{
Embryonic and larval development of Brycon amazonicus (SPIX \& AGASSIZ, 1829)
}

\author{
A. C. S. Sampaio Nakauth ${ }^{a *}$, M. A. Villacorta-Correa ${ }^{b}$, M. R. Figueiredo ${ }^{c}$, G. Bernardino ${ }^{d}$ \\ and J. M. França ${ }^{d}$
}
${ }^{a}$ Colegiado de Ciências Agrárias e do Ambiente, Instituto Natureza e Cultura, Universidade Federal do Amazonas - UFAM, Rua Primeiro de Maio, s/n, Bairro Colônia, CEP 69630-000, Benjamin Constant, AM, Brazil
bDepartamento de Ciências Pesqueiras, Faculdade de Ciências Agrárias, Universidade Federal do Amazonas - UFAM, Av. General Rodrigo Otávio Jordão Ramos, 6200, Bairro Coroado I, CEP 69077-000, Manaus, AM, Brazil
cPrograma de Pós-graduação em Aqüicultura, Universidade Federal do Rio Grande - FURG,
Av. Itália, Km 8, Bairro Carreiros, 475, Aeroporto, CEP 96203-900, Rio Grande, RS, Brazil

${ }^{d}$ Centro de Tecnologia, Treinamento e Produção em Aqüicultura, Secretaria Executiva Adjunta de Pesca e Aqüicultura, Av. Buriti, 1850, Distrito Industrial, CEP 69075-000, Manaus, AM, Brazil

*e-mail:cherolyne@gmail.com

Received: July 28, 2014 - Accepted: December 8, 2014 - Distributed: February 29, 2016

(With 2 figures)

\begin{abstract}
The objective of this study was to describe the embryonic and larval development of Brycon amazonicus, featuring the main events up to 50 hours after fertilization (AF). The material was provided by the Aquaculture Training, Technology and Production Center, Presidente Figueiredo (AM). The characterization was based on stereomicroscopic examination of the morphology of eggs, embryos and larvae and comparison with the literature. Matrinxã eggs are free, transparent, and spherical, with a perivitelline space of $0.56 \pm 0.3 \mathrm{~mm}$. The successive divisions give rise to cells with 64 blastomeres during the first hour AF. The gastrula stage, beginning $02 \mathrm{~h} 40 \mathrm{~min}$ AF, was characterized by progressive regression cells and the formation of the embryonic axis, leading to differentiation of the head and tail $05 \mathrm{~h} 30 \mathrm{~min}$ AF. From 06 to $09 \mathrm{~h} \mathrm{AF}$ the somites, notochord, otic and optic vesicles and otoliths were observed, in addition to heart rate and the release of the tail. The larvae hatched at $10 \mathrm{~h} 30 \mathrm{~min} \mathrm{AF}\left(29.9^{\circ} \mathrm{C}\right)$, with a total length of $3.56 \pm 0.46 \mathrm{~mm}$. Between 19 and $30 \mathrm{~h} \mathrm{AF}$, we observed 1) pigmentation and gut formation, 2) branchial arches, 3) pectoral fins, 4) a mouth opening and 5) teeth. Cannibalism was initiated earlier ( $34 \mathrm{~h} \mathrm{AF})$ which was associated with rapid yolk absorption (more than $90 \%$ until $50 \mathrm{~h} \mathrm{AF}$ ), signaling the need for an exogenous nutritional source. The environmental conditions (especially temperature) influenced the time course of some events throughout the embryonic and larval development, suggesting the need for further studies on this subject.
\end{abstract}

Keywords: matrinxã, embryogenesis, oocytes.

\section{Desenvolvimento embrionário e larval de Brycon amazonicus (SPIX \& AGASSIZ, 1829)}

\begin{abstract}
Resumo
O objetivo deste trabalho foi descrever o desenvolvimento embrionário e larval do Brycon amazonicus, caracterizando os principais eventos ocorridos até 50 h Após Fertilização (AF). O material é proveniente do Centro de Treinamento, Tecnologia e Produção em Aqüicultura em Presidente Figueiredo (AM). A caracterização foi feita com base na análise estereomicroscópica da morfologia dos ovos, embriões e larvas e comparação bibliográfica. Os ovos da matrinxã são livres, transparentes, esféricos com espaço perivitelínico de $0,56 \pm 0,3 \mathrm{~mm}$. As sucessivas clivagens originam células com 64 blastômeros na primeira hora AF. A gástrula, iniciada 02 h e 40 min AF caracterizou-se por progressiva involução celular e formação do eixo embrionário, culminando com diferenciação de cabeça e cauda com 05 h 30 min AF. De 06 às $09 \mathrm{~h}$ AF foi observada a formação de somitos, notocorda, vesículas óptica, ótica e otólitos, além de batimentos cardíacos e liberação da cauda. As larvas eclodiram com $10 \mathrm{~h} 30 \mathrm{~min} \operatorname{AF}\left(29,9^{\circ} \mathrm{C}\right)$, com $3,56 \pm 0,46 \mathrm{~mm}$ de comprimento total. Entre 19 e $30 \mathrm{~h} \mathrm{AF}$ foram observadas: 1) pigmentação e formação do tubo digestivo 2) surgimento de arcos branquiais 3) nadadeira peitoral 4) abertura da boca e 5) surgimento dos dentes. O canibalismo iniciou mais precocemente $(34 \mathrm{~h} \mathrm{AF})$, em relação aos trabalhos existentes com o gênero, o que associado à rápida absorção do vitelo (mais de $90 \%$ até $50 \mathrm{~h} \mathrm{AF}$ ), sinaliza a necessidade de ofertar recurso alimentar exógeno. As condições ambientais (especialmente temperatura e $\mathrm{pH}$ ) influenciaram na abreviação de alguns eventos ao longo do desenvolvimento embrionário e larval, sugerindo a necessidade de estudos complementares a esse respeito.
\end{abstract}

Palavras-chave: matrinxã, embriogênese, ovócitos. 


\section{Introduction}

The matrinxã Brycon amazonicus (Spix \& Agassiz, 1829 ) is a rheophilic species native to the Amazon basin, which has great potential as a fish farming region, both in semi-intensive and intensive systems (Zaniboni-Filho et al., 2006). In the taxonomic revision of the genus Brycon, Lima (2003) concluded that the species Brycon cephalus, which lives in the Brazilian Amazon and is widely cultivated in Brazil, is in fact Brycon amazonicus, which is also synonymous with the species Brycon siebenthalae.

One of the barriers to aquaculture growth of this species is related to low survival in the larval stage, where cannibalism has been recorded as the main cause of death (Bernardino et al., 1993; Faria, 1994; Lopes et al., 1995; Ceccarelli and Volpato, 2001; Leonardo et al., 2008). To conduct research on this native species, knowledge of the early stages of fish embryonic development is extremely important. The use of information on embryogenesis allows us to characterize morphological and chronological events that are important for studies on reproduction and growth (Reynalte-Tataje et al., 2001), taxonomy (Leite et al., 2006), and environmental quality assessment (Flores et al., 2002). In fish culture, this information provides insight into the life cycle of the fish species (Ninhaus-Silveira et al., 2006) and may be a predictive tool to assess the viability of eggs after fertilization (Shields et al., 1997; Kjorsvik et al., 2003). In fish farms for juvenile production, the knowledge about embryonic development supports incubation management of water quality that could lead to abnormalities and low productivity in farming (Reynalte-Tataje et al., 2004). Thus, the identification and description of the main events during the embryonic development of $B$. amazonicus are justifiable, especially because of the scarcity of information that can be applied in regional studies, where differences in temperature could be significant for optimizing larval rearing in laboratory conditions. This study aims to describe and characterize the main events during the stages of embryonic and larval development of the matrinxã $B$. amazonicus.

\section{Material and Methods}

The experiment was conducted at the Fish Culture Station of the Center for Technology, Training and Production in Aquaculture (CTTPA), located in the village of Balbina, Presidente Figueiredo, Amazonas, in February 2010. For this work, we used $B$. amazonicus breeders acquired from the tributaries of the Black River and kept during the breeding season in a nursery of $600 \mathrm{~m}^{3}$ at a density of $300 \mathrm{~g} / \mathrm{m}^{2}$. The selection of animals for induction was based on Woynarovich and Horvath (1983). The selected fish were induced according to the protocol described by Bernardino et al. (1993). After fertilization, the eggs were placed in 60-1 conical glass fiber incubators at a density of $1 \mathrm{~g} \cdot 1^{-1}$ until $50 \mathrm{~h} \mathrm{AF}$.

Samples that contained 10 eggs or larvae were collected during embryonic and larval development for observations in vivo in a stereomicroscope and then fixed in $4 \%$ formaldehyde for further confirmation. The collection started at the moment of fertilization, considered zero time. The samples were taken at intervals of 10 min up to $10 \mathrm{~h}$ after fertilization (AF). Between 10 and $17 \mathrm{~h} \mathrm{AF}$, the intervals were $30 \mathrm{~min}$, and between 18 and $50 \mathrm{~h} \mathrm{AF}$, the samples were collected every 02 hours.

For morphometric characterization of dry fertilized eggs, perivitelline space (PS) and mouth opening and total length of newly hatched larvae were measured for 100 specimens with an ocular micrometer adapted on a stereomicroscope. To determine the size of the mouth opening, we referred to the protocol outlined by Shirota (1970).

\section{Results}

The physical-chemical water parameters were $\mathrm{pH}$ $5.20 \pm 0.21$, oxygen $6.70 \pm 0.16 \mathrm{mg} / 1$ and temperature $29.97 \pm 0.19{ }^{\circ} \mathrm{C}$. The main events recorded at each stage of embryonic and larval development were presented in chronological order (Table 1), divided into two stages, the embryonic and larval stages, and the main characteristics were described based on external features.

After extrusion, the "matrinxã" oocytes had an olive green coloration, which remained until the end of embryonic development by staining of the yolk sac. The diameter of the dry fertilized egg was $1.28 \pm 0.19 \mathrm{~mm}$, and the animal pole was darker than the vegetative pole, which was light-colored and opaque. After 10 minutes of hydration, the eggs were $1.84 \pm 0.21 \mathrm{~mm}$ in diameter, with the PS measuring $0.56 \pm 0.3 \mathrm{~mm}$.

The "matrinxã" eggs are meroblastic, telolecithal and discoidal (Wolpert et al., 2000). The first cleavages were observed 20 minutes after fertilization (AF), yielding cells with $02,04,08,16,32$ and 64 blastomeres. As the targeting cell increases, the degree of compaction intensifies between blastomeres, hindering their individual observations. This event was observed $01 \mathrm{~h} 20 \mathrm{~min}$ AF.

The early gastrula was observed $02 \mathrm{~h} 40 \mathrm{~min}$ AF (Figure 1a), and the $100 \%$ epiboly stage was observed $05 \mathrm{~h} 10 \mathrm{~min}$ AF (Figure 1g). After somatic targeting, the differentiation of the head and tail began $5 \mathrm{~h} 30 \mathrm{~min}$ AF (Figure $1 \mathrm{~h}$ ), as did the appearance of somites in increasing numbers, reaching 32 somites $50 \mathrm{~min}$ before hatching (Figures 1i, 1j, 1k and 11). Otic and optical vesicles were observed between 6 and $8 \mathrm{~h} \mathrm{AF} \mathrm{(Figure} \mathrm{2b).}$

Otoliths initially in two pairs were observed $8 \mathrm{~h} 20 \mathrm{~min} A F$ within the optic vesicle and became larger and more distinct as the larvae grew. After $15 \mathrm{~h} 30 \mathrm{~min} \mathrm{AF}$, otoliths were clearly observed in three pairs (Figure 2d). The first heartbeat and circulation were observed 09 h $10 \mathrm{~min}$ AF, coinciding with the observation of 32 somites on the axis of the notochord, more easily seen at this stage. The tail partially detached from the calf was more elongated, and light muscle contractions were observed and spaced, which intensified the proximity of hatching. Notochord and myomeres were easily observed $09 \mathrm{~h} 10 \mathrm{~min}$ AF.

As the embryo movement flow intensified, there was a progressive weakening and rupture of the chorion, an event 
Table 1. Time at which major morphological observations during embryonic and larval development of B. amazonicus occurred. Incubation temperature $29.97^{\circ} \mathrm{C} \pm 0.18$.

\begin{tabular}{|c|c|c|c|}
\hline Stage & Phase & $\begin{array}{c}\text { Time after } \\
\text { fertilization (AF) }\end{array}$ & Description \\
\hline \multirow{13}{*}{ 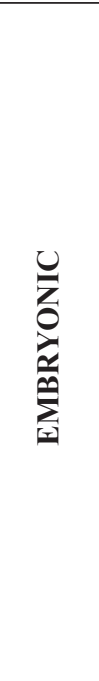 } & \multirow{6}{*}{ Cleavage } & $00^{\prime}$ & Egg after fertilization will dry \\
\hline & & $10^{\prime}$ & Training perivitelline space \\
\hline & & $20^{\prime}$ at $1 \mathrm{~h} 10^{\prime}$ & $\begin{array}{l}\text { Successive cell divisions resulting in } 02,04,08,16,32 \text { and } \\
64 \text { blastomeres }\end{array}$ \\
\hline & & 1 h $20^{\prime}$ a 1 h $40^{\prime}$ & Epiboly $30 \%$ \\
\hline & & 1 h 50' a 2 h 40' & Epiboly $50 \%$, early gastrulation \\
\hline & & 2 h $40^{\prime}$ a 5 h $10^{\prime}$ & Epiboly $100 \%$ \\
\hline & \multirow{7}{*}{ Embryogenesis } & $06 \mathrm{~h}$ & $\begin{array}{l}\text { The calf gets an almond-like shape, showing the shape of the } \\
\text { embryo; the head and tail can be distinguished }\end{array}$ \\
\hline & & $06 \mathrm{~h} 10^{\prime}$ & Display of the first 5 somites \\
\hline & & $6 \mathrm{~h} 30$ ' & Emergence of the optic vesicle \\
\hline & & $7 \mathrm{~h}$ & View of 10 somites \\
\hline & & 8 h 20, & $\begin{array}{l}\text { Emergence of otic vesicle and visualization of two pairs of } \\
\text { otoliths; early detachment of the tail and calf }\end{array}$ \\
\hline & & $9 \mathrm{~h} \mathrm{10}$ & First heart rate and view of 32 somites \\
\hline & & 9 h 20’- 9 h $30^{\prime}$ & Early movement of the tail \\
\hline \multirow{12}{*}{ 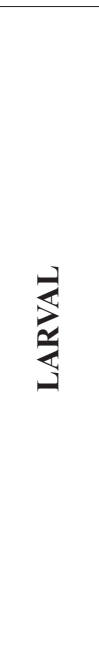 } & \multirow{12}{*}{ Organogenesis } & 10 h- 10 h 30 & $\begin{array}{l}\text { Intensification of movement for hatching; asynchronous } \\
\text { hatching, non-pigmented larvae, first movements of } \\
\text { swimming }\end{array}$ \\
\hline & & 15 h 30 & $\begin{array}{l}\text { Delineation of oral cleft; clear observation of the auditory } \\
\text { capsule and three pairs of otoliths }\end{array}$ \\
\hline & & 18 h 30 ’ & Top of the retinal pigment epithelium \\
\hline & & $19 \mathrm{~h}$ & Start training the digestive tract \\
\hline & & $26 \mathrm{~h}$ & Note the gill arches and distinctive pectoral fins \\
\hline & & $28 \mathrm{~h}$ & Opening of the mouth \\
\hline & & $30 \mathrm{~h}$ & Emergence of teeth \\
\hline & & $34 \mathrm{~h}$ & Start of cannibalism \\
\hline & & $36 \mathrm{~h}$ & $\begin{array}{l}\text { Total retinal pigmentation and expansion of chromatophores } \\
\text { on the cranial region }\end{array}$ \\
\hline & & $38 \mathrm{~h}$ & Expansion of chromatophores on the pectoral region \\
\hline & & $40 \mathrm{~h}$ & Apparent absorption of 40 to $70 \%$ of the calf \\
\hline & & $50 \mathrm{~h}$ & Apparent absorption of more than $90 \%$ of the calf \\
\hline
\end{tabular}

recognized as hatching, which occurred asynchronously from $10 \mathrm{~h} \mathrm{AF} ; 50 \%$ of individuals hatched at $10 \mathrm{~h} 30 \mathrm{~min}$ AF. The size of newly hatched larvae was $3.56 \pm 0.46 \mathrm{~mm}$, without retinal pigmentation. The yolk sac was the main visible structure, which highlights the presence of the calf, with intense olive coloration. Chromatophores distributed on the retina could only be observed $18 \mathrm{~h} 30 \mathrm{~min}$ AF (Figure 2c).

Pectoral fins and first gill arches (Figure 2d) were observed at $26 \mathrm{~h} \mathrm{AF}$, which was when a deepening of the epithelium of the inlet mouth was also observed, resulting in the oral cavity opening at $28 \mathrm{~h} \mathrm{AF}$. Denticles were observed starting at $30 \mathrm{~h} \mathrm{AF}$ and were fully developed at $34 \mathrm{~h} \mathrm{AF}$, which was when cannibalism started. The denticles were presented as well-developed, conical shapes that turned back. The newly hatched larvae exhibited erratic vertical swimming characterized by upward movement, followed by constant sinking in the water column.

At $33 \mathrm{~h} \mathrm{AF}$, swimming larvae presented intense and consecutive jaw movements followed by frequent attacks $34 \mathrm{~h} \mathrm{AF}$. At this phase, the retina was partly pigmented, the diameter of the eyes was $0.30 \pm 0.13 \mathrm{~mm}$, the yolk sac was remarkably reduced, and the mouth opening was $1.42 \pm 0.18 \mathrm{~mm}, 23.01 \%$ of the standard length $(6.17 \pm 0.38 \mathrm{~mm})$.

On the matrinxã, dendritic chromatophores were clearly observed on the cranial region and yolk sac $36 \mathrm{~h} \mathrm{AF}$; then, there was total retinal pigmentation $38 \mathrm{~h} \mathrm{AF}$. At this time, the body pigmentation extended over the pectoral region, with greater intensity in the cranial and lateral regions. The distribution of pigment in the body permits better survival of the larvae, related to masking, as at this stage the larvae are susceptible to predation, and represents 

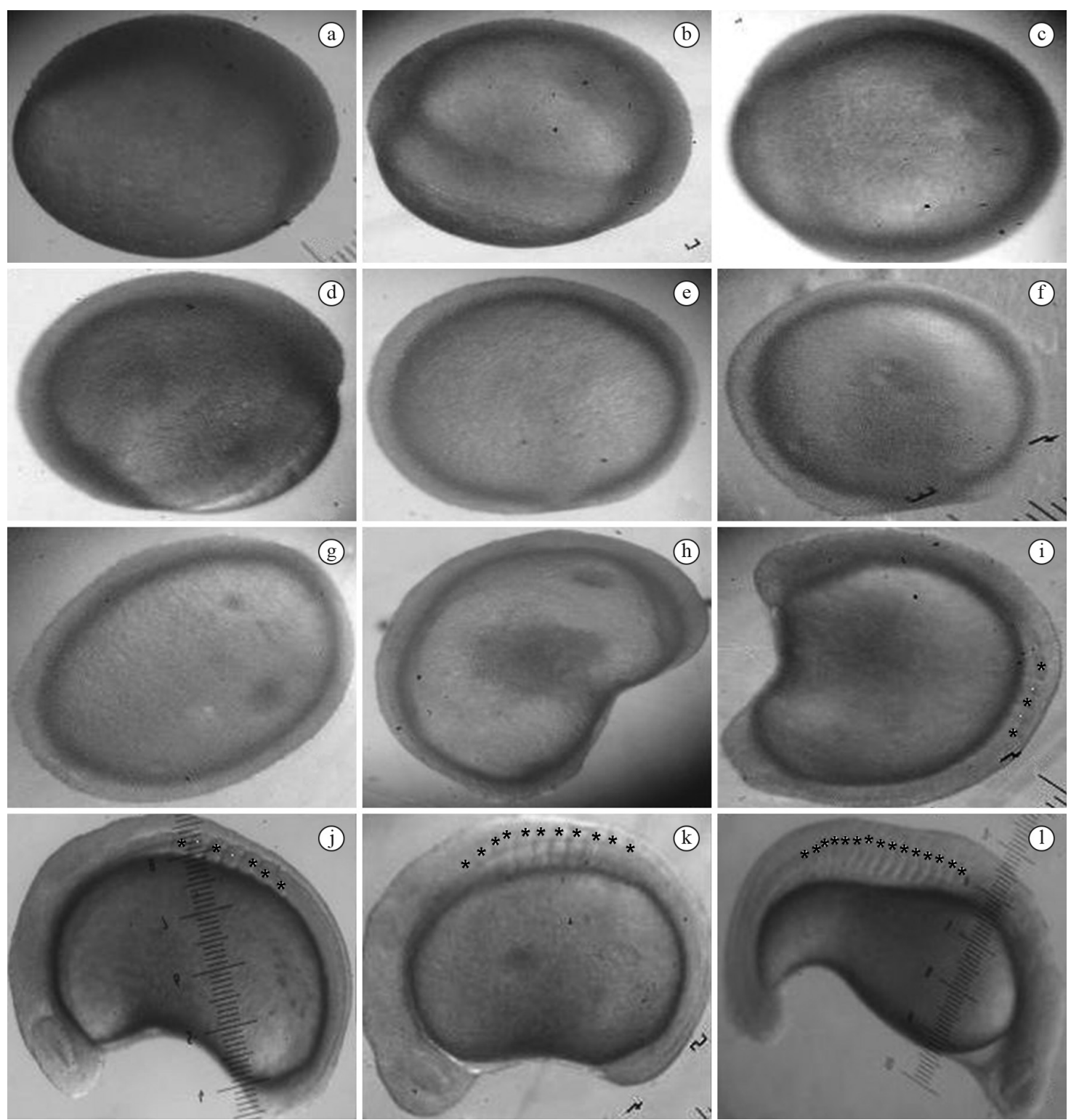

Figure 1. Embryonic development of B. amazonicus $\left(29.9^{\circ} \mathrm{C}\right)$. (a) early gastrula $(50 \%$ epiboly, $2 \mathrm{~h} 40$ min $\mathrm{AF})$, advanced gastrula in (b) 3 h 30 min AF; (c) 4 h 10 min; (d) 4 h 40 min; and (e) 5 h AF; /9F); (f) and (g): end of gastrula (100\% epiboly to $5 \mathrm{~h} 10 \mathrm{~min} \mathrm{AF})$; (h) early differentiation of head and tail ( $5 \mathrm{~h} 30 \mathrm{~min} \mathrm{AF}),(\mathrm{i}, \mathrm{j}, \mathrm{k}$ and 1 ) emergence of somites $5,7,11$ and 15 , respectively; $(*)$ highlights the somites.

specific features used in taxonomy. Larvae $38 \mathrm{~h}$ AF present calves with an apparent reduction of $80 \%$ over the initial volume (newly hatched).

Between $40 \mathrm{~h}$ and $44 \mathrm{~h} \mathrm{AF}$, it was observed that the larvae mouth was completely opened with sharp teeth, a differentiated and slightly yellowish digestive tract and dark pigmentation on the intestine. From 46 to $48 \mathrm{~h} \mathrm{AF}$, it was possible to distinguish blood circulation through reddish flow, and the yolk was almost totally absorbed. At $50 \mathrm{~h} \mathrm{AF}$, larvae swam horizontally, and several cannibalism episodes were confirmed by observation of partially ingested larvae.

\section{Discussion}

The morphological and morphometric characteristics of dry fertilized eggs and hydrated eggs were similar to those reported in other studies using Brycon (Bernardino et al., 1993; Lopes et al., 1995; Romagosa et al., 2001; Clavijo-Ayala and Arias Castellanos 2004; Nakaghi et al., 2013). The matrinxã's pattern of development is similar to that reported by Kimmel et al. (1995) for zebra fish, in which the blastoderm is formed by a single outer layer of flattened cells, known as the involucral outer layer, and a more rounded deep layer of cells. The increase of 

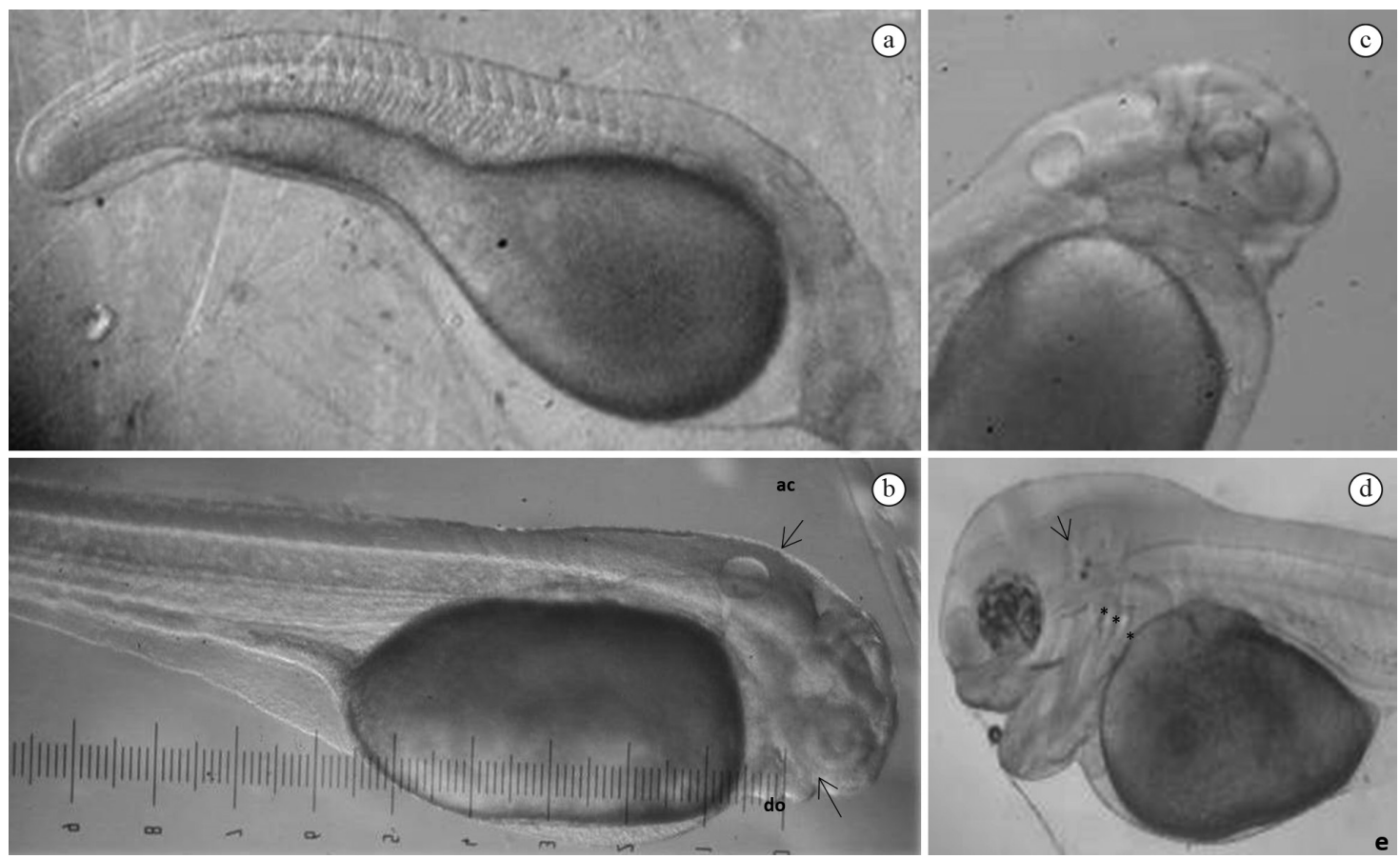

Figure 2. Embryonic development of $B$. amazonicus $\left(29.9^{\circ} \mathrm{C}\right)$. (a) newly hatched larva (10 h AF); (b) delineation of oral cleft (do), viewing the auditory capsule with otoliths (ac) (15 h 30 min AF); (c) retinal pigmentation (18 h $30 \mathrm{~min} A F)$; (d) gill arches $\left(^{*}\right)$; and clear observation of otoliths and pectoral fin (arrows) (16 h AF).

cell segmentation enhances the degree of compaction between blastomeres and marks the end of the ball stage (Wolpert et al., 2000), also referred to as morula and early blastula (Andrade-Talmelli et al., 2001; Reynalte-Tataje et al., 2001; Romagosa et al., 2001; Anjos and Anjos, 2006; Ninhaus-Silveira et al., 2006; Faustino et al., 2007; Paes, 2008; Nakaghi et al., 2013).

The beginning of gastrula marks the end of the blastula stage, and it is followed by epiboly, defined as the movement of the yolk syncytial layer and blastodisc around the yolk cell. Epiboly starts with the deep layer cells radially intercalating and the yolk cell "doming," which was recorded by Andrade-Talmelli et al. (2001) and Paes (2008) when eggs presented with $30 \%$ epiboly and by Kimmel et al. (1995) and Sampaio (2006) when it was in the $50 \%$ epiboly stage. With B. amazonicus, Clavijo-Ayala and Arias Castellanos (2004) observed the early gastrula ( $10 \%$ epiboly) at $5 \mathrm{~h} \mathrm{AF}\left(27.5 \pm 0.2^{\circ} \mathrm{C}\right)$, and Nakaghi et al. (2013) observed the beginning of the epiboly and gastrula stage when cell proliferation covered approximately $30 \%$ of the yolk, at $3 \mathrm{~h} \mathrm{AF}\left(28.08^{\circ} \mathrm{C}\right)$. We observed the same event $1 \mathrm{~h} 20 \mathrm{~min} \operatorname{AF}\left(29.9 \pm 0.18^{\circ} \mathrm{C}\right)$, and the difference could be related to temperature.

Clavijo-Ayala and Arias Castellanos (2004) indicated that high incubation temperatures $\left(30^{\circ} \mathrm{C}\right)$ lead to exogastrulation (protusion of yolk mass) in B. amazonicus oocytes due to enzymes and proteins that participate in the formation and performance of microtubules and the direction of epibolic movements.
The gastrulation stage ends when the blastoderm completely covers the yolk, characterizing the $100 \%$ epiboly stage, which is marked by the presence of primary germ layers (endoderm, mesoderm and ectoderm) and the embryonic axis, giving rise to the subsequent stage characterized by organogenesis (Wolpert et al., 2000). Some authors consider the $100 \%$ epiboly stage equivalent to the closure of the blastopore and attribute this moment the opening of the primitive gut in larvae.

In this work, the temperature most likely influenced gastrulation, observed earlier $\left(5 \mathrm{~h} 10 \mathrm{~min} \mathrm{AF}, 29.9 \pm 0.18^{\circ} \mathrm{C}\right)$ than what was recorded by Neumann (2008) $(6 \mathrm{~h} \mathrm{AF}$, $27^{\circ} \mathrm{C}$ ) and Clavijo-Ayala and Arias Castellanos (2004) $\left(6.5 \mathrm{~h} \mathrm{AF}, 27.5^{\circ} \mathrm{C}\right)$ for $B$. amazonicus eggs and later compared with $B$. insignis ("piabanha") $\left(4 \mathrm{~h} \mathrm{AF}, 26.1^{\circ} \mathrm{C}\right)$ (Andrade-Talmelli et al., 2001).

During gastrulation, the mesoderm that has moved into the embryo is positioned in the block side of the notochord, a structure that supports the spinal cord and extends from head to tail in a central position (Paes, 2008). Blocks of mesoderm positioned beside the notochord give rise to the muscles, limbs, spine and dermis, called somites, which segment, forming myomeres widely used in taxonomic studies of fishes (Araújo-Lima and Donald, 1988; Wolpert et al., 2000).

The emergence of ocular and auditory capsules marks the beginning of the development of sensory structures in fish larvae and is an event that often follows the emergence of myomeres in different species (Reynalte-Tataje et al., 2001; 
Sanches et al., 2001; Ninhaus-Silveira et al., 2006; Pereira et al., 2006; Clavijo-Ayala, 2008). As observed by Falk-Petersen (2005), at the stage at which these capsules emerge, larvae have no stability in water, coordination of movements, or visual acuity. In B. amazonicus, optics and optical capsules were observed between 6 and $8 \mathrm{~h} \mathrm{AF}$, coinciding with the results for $B$. cephalus, as observed by Romagosa et al. (2001) $\left(26^{\circ} \mathrm{C}\right)$, Lopes et al. (1995) $\left(30^{\circ} \mathrm{C}\right)$ and Alexandre et al. $(2010)\left(26^{\circ} \mathrm{C}\right)$.

The embryonic development of $B$. amazonicus has been reported in the literature, ranging from $10 \mathrm{~h} 30 \mathrm{~min} \mathrm{AF}$ (in this work and Lopes et al., 1995), to $11 \mathrm{~h} \mathrm{AF}$ (Romagosa et al., 2001- $26^{\circ} \mathrm{C}$ ), $13 \mathrm{~h} \mathrm{AF}$ (Nakaghi et al., 2013- $28.08^{\circ} \mathrm{C}$ ) and $13 \mathrm{~h} 30 \mathrm{~min}$ AF (Mira-López et al., $2007-28.02{ }^{\circ} \mathrm{C}$ ). For $B$. orbignyanus, hatching was recorded at $18 \mathrm{~h} 30 \mathrm{~min} \mathrm{AF}$ (Reynalté-Tataje et al., 2001- $25^{\circ} \mathrm{C}$ ) and $13 \mathrm{~h} \mathrm{AF}$ (Landines-Parra, 2003; Landines-Parra et al., 2003- $28.01^{\circ} \mathrm{C}$ ). Temperature can speed up or slow down larvae hatching (Trejo and Martinez, 1983), mainly for tropical fishes, where there is a direct correlation between water temperature and embryonic development (Johnston and Vieira, 1996).

For B. amazonicus, Clavijo Ayala and Arias Castellanos (2004) observed that the increase of incubation temperature decreases the duration of embryonic development but also increases the occurrence of deformed embryos. All oocytes incubated at $32{ }^{\circ} \mathrm{C}$ shattered by $3 \mathrm{~h}$ Kamler and Keckeis (1988) associated deformations and death in the eggs and embryos of fish at different stages of development with the proteins denaturing or the inactivation of enzymes when subjected to temperatures too low or too high.

The relatively fast embryonic development is a common characteristic among species with reproductive strategies that involve migration and spawning in lotic environments (Sanches et al., 2001), and for the genus Brycon, it can be considered an advantage in the reproduction process (Andrade-Talmelli et al., 2001; Romagosa et al., 2001).

In relation to the size of newly hatched larvae, B. orbignyanus ("piracanjuba") (Andrade Talmelli et al., 2001) and B. insignis ("piabanha") (Reynalte-Tataje et al., 2004) were bigger than B. amazonicus ("matrinxã") (this work; Mira-López et al., 2007; Romagosa et al., 2001; Lopes et al., 1995). In addition to species-specific characteristics, the water temperature of incubation influences the size of newly hatched larvae and early development (Curiacos, 1999).

The pigmentation of the retina is related to the functionality of the eyes (Falk-Petersen, 2005), and this event was completed in B. amazonicus between 32 and $36 \mathrm{~h}$ after hatching $\left(25^{\circ} \mathrm{C}\right)$ (Arias Castellanos et al., 2003) and between 21 and $24 \mathrm{~h}$ after hatching $\left(27^{\circ} \mathrm{C}\right.$ ) (Mira-López et al., 2007). The absence of pigmentation in the body from the moment of hatching possibly implies delayed development of the visual system, which in turn delays the capture of prey but does not delay the development of additional sensory systems (Roo et al., 1999; Clavijo-Ayala, 2008). In this work, chromatophores distributed on the retina could only be observed in B. amazonicus at $18 \mathrm{~h} 30 \mathrm{~min}$ $\mathrm{AF}$, and it was totally pigmented approximately $36 \mathrm{~h} \mathrm{AF}$.

Pectoral fins and first gill arches were observed at $26 \mathrm{~h} \mathrm{AF}$, a similar period to that reported by Mira-López et al. (2007) for B. amazonicus (between $28 \mathrm{~h} 30 \mathrm{~min}$ and $31 \mathrm{~h} 30 \mathrm{~min} \mathrm{AF}$ ). According to Paes (2008), the appearance of the pectoral fin is an important event in the organogenesis of fish larvae because these structures facilitate the balance and direction in the water column. This structure, emerging together with the opening of the oral cavity $28 \mathrm{~h} \mathrm{AF}$, signals the larvae's ability to search for exogenous food. Silva et al. (2007), however, verified through histological analysis the presence of an oropharyngeal membrane despite the presence of denticles, as described by Ceccarelli (1997) and Romagosa et al. (2001). Neumann (2008), observed denticles in B. amazonicus only $35 \mathrm{~h} \mathrm{AF}\left(27.98 \pm 0.81^{\circ} \mathrm{C}\right)$.

The erratic vertical swimming is associated with the process of filling the bladder (Maciel et al., 2010). This behavior, associated with consecutive mandibular movements followed by frequent attacks at $34 \mathrm{~h} \mathrm{AF}$, could be associated with the mechanism for developing muscular and skeletal structures involved in the capture and arrest of the first food (Herbing, 2001).

Cannibalism, observed $34 \mathrm{~h} \mathrm{AF}$, presents earlier compared with other studies on B. amazonicus (Bernardino et al., 1993 and Lopes et al., 1995), $46 \mathrm{~h} \mathrm{AF}\left(30{ }^{\circ} \mathrm{C}\right)$ and Romagosa et al. (2001), $36 \mathrm{~h} \mathrm{AF}\left(26^{\circ} \mathrm{C}\right)$. Ceccarelli (1997) describes a sequence of events that characterizes the observed cannibalism: fixing the prey, approach, boat, bite and apprehension. At $38 \mathrm{~h} \mathrm{AF}$, the larvae presents considerable calf reduction (Neumann, 2008), indicating an apparent ability to begin an important stage in the transition from endogenous (yolk) to exogenous (live or artificial food) nutrition.

At $48 \mathrm{~h} \mathrm{AF}$, the juveniles are able to perform the first feeding because the yolk sac is now almost non-existent, and stomach and intestine are well-differentiated (Mira-López et al., 2007). They present similar structures to those of adult specimen, with a completely pigmented body, well-formed caudal and pectoral fins, and silvery scales. Matrinxã starts feeding at the end of the first day (Romagosa et al., 2001). Despite variation in the register of cannibalism occurrence ( 34 to $36 \mathrm{~h} \mathrm{AF}$ ), the intensification of this behavior at $50 \mathrm{~h} \mathrm{AF}$ signals the need to intervene in the management practices through the provision of exogenous food, aiming to minimize the effect of cannibalism on larval mortality.

\section{Conclusions}

The "matrinxã" B. amazonicus has fast embryonic and larval development, thus requiring differentiated management during the initial phase. Their ability to hunt and capture is evidenced by cannibalistic behavior, as aforementioned in relation to other fish with the genus Brycon.

The fast depletion of yolk signals the need for supplementary feeding, allowing minimization of the loss due to cannibalism, which optimizes growth. Future studies 
are needed to further evaluate the effect of temperature and $\mathrm{pH}$ on the embryonic and larval development, aiming to standardize the hatching protocol for the species.

\section{Acknowledgements}

The National Counsel of Technological and Scientific Development (CNPq), Foundation for Research of the State of Amazonas (FAPEAM), Federal University of Amazonas (UFAM) and Ministry of Rural Production in Amazonas (SEPROR).

\section{References}

ALEXANDRE, J.S., NINHAUS-SILVEIRA, A., VERÍSSIMOSILVEIRA, R., BUZOLLO, H., SENHORINI, J.A. and CHAGURI, M.P., 2010. Structural analysis of the embryonic development in Brycon cephalus (Günther, 1869). Zygote, vol. 18, no. 2, pp. 173-183. PMid:19943981.

ANDRADE-TALMELLI, E.F., KAVAMOTO, E.T., ROMAGOSA, E. and FENERICH VERANI, N., 2001. Embrionic and larval development of the "piabanha", Brycon insignis, STEINDACHNER, 1876 (PISCES, CHARACIDAE). Boletim do Instituto de Pesca, vol. 27, no. 1, pp. 21-28.

ANJOS, H.D.B. and ANJOS, C.R., 2006. Biologia reprodutiva e desenvolvimento embrionário e larval do cardinal tetra, Paracheirodon axelrodi SCHULTZ, 1956 (Characiformes: Characidae), em laboratório. Boletim do Instituto de Pesca, vol. 32, no. 2, pp. 151-160.

ARAUJO-LIMA, C.A. and DONALD, E., 1988. Número de vértebras de Characiformes do Rio Amazonas e seu uso na identificação de larvas do grupo. Acta Amazonica, vol. 18, no. 1-2, pp. 351-358. http://dx.doi.org/10.1590/1809-43921988182358.

ARIAS CASTELLANOS, J.A., BALAGUERA, D. and RODRIGUEZ SIERRA, C.M., 2003. Desarrollo larvario del yamú Brycon siebenthalae. Orinoquia, vol. 7, no. 1-2, pp. 28-33.

BERNARDINO, G., SENHORINI, J.A., BOCK, C.L. and MENDONÇA, J.O.J., 1993. Propagação artificial do matrinchã Brycon cephalus (Günther, 1869) (Teleostei, Characidae). Boletim Técnico do CEPTA, vol. 6, no. 2, pp. 1-9.

CECCARELLI, P.S., 1997. Canibalismo de larvas de matrinxã, Brycon cephalus, (Günther, 1869). Botucatu: Universidade Estadual Paulista, 80 p. Masters Dissertation.

CECCARELLI, P.S. and VOLPATO, G.L., 2001. Efeitos da densidade e proporção de presas consorciadas no crescimento e sobrevivência de matrinxã (Brycon cephalus). Boletim Técnico do CEPTA, vol. 14, pp. 1-18.

CLAVIJO-AYALA, J.A., 2008. Ontogenia do sistema sensorial do pacu Piaractus mesopotamicus, (HOLMBERG, 1887) (CHARACIDAE: SERRASALMIDAE). Jaboticabal: Centro de Aqüicultura, Universidade Estadual Paulista, 45 p. Masters Dissertation.

CLAVIJO-AYALA, J.A., ARIAS CASTELLANOS, J.A., 2004. Avances en el estudio de la embriologia del yamu Brycon siebenthalae (PISCES: CHARACIDAE). Revista Dahlia, no. 7, pp. 37-48.

CURIACOS, A.P.J., 1999. Efeito da temperatura no desenvolvimento inicial de larvas de "curimbatá" Prochilodus scrofa Steindachner,
1881 (Characiformes, Prochilodontidae). Florianópolis: Universidade Federal de Santa Catarina, 91 p. Masters Dissertation. $</$ ths $>$.

FALK-PETERSEN, I.B., 2005. Comparative organ differentiation during early life stages of marine fish. Fish \& Shellfish Immunology, vol. 19, no. 5, pp. 397-412.http://dx.doi.org/10.1016/j.fsi.2005.03.006 PMid:15890533.

FARIA, C.A., 1994. Propagação artificial da piabanha (Brycon insignis). In: Anais do Seminário Sobre a Criação de Espécies do Gênero Brycon, 1994, Pirassununga, Brasil. São Paulo: CEPTA, pp. 9-15.

FAUSTINO, F., NAKAGHI, L.S.O., MARQUES, C., MAKINO, L.C. and SENHORINI, J.A., 2007. Fertilização e desenvolvimento embrionário: morfometria e análise estereomicroscópica dos ovos dos híbridos de surubins (pintado, Pseudoplatystoma corruscans x cachara, Pseudoplatystoma fasciatum). Acta Scientiarum: Biological Sciences, vol. 29, no. 1, pp. 49-55.

FLORES, J.C.B., ARAIZA, M.A.F. and VALLE, M.R.G., 2002 [viewed 25 April 2010]. Desarrollo embrionario de Ctenopharyngodon edellus (Carpa herbívora). In: I Congreso Iberoamericano Virtual de Acuicultura (CIVA 2002) [online], 2002, España. España: Revista AquaTIC, pp. 792-797. Available from: http://www. revistaaquatic.com/civa2002/

HERBING, H.V., 2001. Development of feeding structures in larval fish with different life histories: winter flounder and Atlantic cod. Journal of Fish Biology, vol. 59, no. 4, pp. 767-782. http:// dx.doi.org/10.1111/j.1095-8649.2001.tb00148.x.

JOHNSTON, I.A. and VIEIRA, V.L.A., 1996. Larval development in the tambaqui (Colossoma macropomum) and curimatã-pacu (Prochilodus marggravii). In: A.L. VAL, V.M.F. ALMEIDA-VAL and D.J. RANDALL, eds. Physiology and Biochemistry of Fishes of the Amazon. Manaus: INPA, pp. 43-55.

KAMLER, E.H. and KECKEIS, E.B., 1988. Temperature-induce $\mathrm{d}$ changes of survival, development and yolk partitioning in Chondrostomo nosus. Journal of Fish Biology, vol. 53, pp. 658-682.

KIMMEL, C.B., BALLARD, W.W., KIMMEL, S.R., ULLMANN, B. and SCHILLING, T.F., 1995. Stages of embryonic development of the zebrafish. Developmental Dynamics, vol. 203, no. 3, pp. 253-310.http://dx.doi.org/10.1002/aja.1002030302 PMid:8589427.

KJØRSVIK, E.E., HOEHNE-REITAN, K. and REITAN, K.I., 2003. Egg and larval quality criteria as predictive measures for juvenile production in turbot (Scophthalmus maximus L.). Aquacult, vol. 227, no. 1-4, pp. 9-20. http://dx.doi.org/10.1016/ S0044-8486(03)00492-7.

LANDINES-PARRA, M.A., 2003. Efeito da triiodotironina (T3) no desenvolvimento embrionário e no desempenho das larvas de pintado (Pseudoplatystoma coruscans), piracanjuba (Brycon orbignyanus) e dourado (Salminus maxillosus). Jaboticabal: Universidade Estadual Paulista, 154 p. PhD Thesis.

LANDINES-PARRA, M.A., SENHORINI, J.A., SANABRIA, A.I. and URBINATI, E.C., 2003. Desenvolvimento embrionário do pintado (Pseudoplatystoma corruscans), AGASSIZ, 1829. Boletim Técnico do CEPTA, vol. 16, pp. 1-13.

LEITE, R.G., SILVA, J.V.V. and FREITAS, C.E.C., 2006. Abundância e distribuição das larvas de peixes no Lago Catalão e no encontro dos rios Solimões e Negro, Amazonas, Brasil. Acta Amazonica, vol. 36, no. 4, pp. 557-562. http://dx.doi.org/10.1590/ S0044-59672006000400018.

LEONARDO, A.F.G., HOSHIBA, M.A., SENHORINI, J.A. and URBINATI, E.C., 2008. Canibalismo em larvas de matrinxã, 
Brycon cephalus, após imersão dos ovos à diferentes concentrações de triiodotironina $\left(\mathrm{T}_{3}\right)$. Boletim do Instituto de Pesca, vol. 34, pp. 231-239.

LIMA, F.C.T., 2003. Subfamily Bryconinae. In: R.E. REIS, S.O. KULLANDER and C.J. FERRARIS, eds. Check list of the freshwater fishes of South and Central America. Porto Alegre: EDIPUCRS, pp. 174-181.

LOPES, R.N.M., SENHORINI, J.A. and SOARES, M.C.F., 1995. Desenvolvimento embrionário e larval do matrinxã Brycon cephalus Günther, 1869, (Pisces, Characidae). Boletim Técnico do CEPTA, vol. 8, pp. 25-39.

MACIEL, C.M.R.R., LANNA, E.A.T., MACIEL JUNIOR, A., DONZELE, J.L., NEVES, C.A. and MENIN, E., 2010. Morphological and behavioral development of the piracanjuba larvae. Revista Brasileira de Zootecnia, vol. 39, no. 5, pp. 961970. http://dx.doi.org/10.1590/S1516-35982010000500004.

MIRA-LÓPEZ, T., MEDINA-ROBLESI, V.M., VELASCOSANTAMARIA, Y.M. and CRUZ-CASALLAS, P.E., 2007. Valores morfométricos em larvas de yamú Brycon amazonicus (Pisces: Characidae) obtenidas com sêmen fresco y crioconservado. Actualidades Biológicas, vol. 29, no. 87, pp. 203-213.

NAKAGHI, L.S.O., NEUMANN, E., FAUSTINO, F., MENDES, J.M.R. and BRAGA, F.M., 2013. Moments of induced spawning and embryonic development of Brycon amazonicus (Teleostei, Characidae). Zygote, vol. 22, no. 4, pp. 549-557.http://dx.doi. org/10.1017/S0967199413000130 PMid:23659693.

NEUMANN, E., 2008. Desenvolvimento inicial de jatuarana Brycon amazonicus (Teleostei, Characidae). Jaboticabal: Universidade Estadual Paulista, 125 p. PhD Thesis.

NINHAUS-SILVEIRA, A., FORESTI, F. and AZEVEDO, A., 2006. Structural and ultrastructural analysis of embryonic development of Prochilodus lineatus (Valenciennes, 1836) (Characiforme, Prochilodontidae). Zygote, vol. 14, no. 3, pp. 217-229.http://dx.doi. org/10.1017/S096719940600373X PMid:16822333.

PAES, M.C., 2008. Indução à reprodução e desenvolvimento embrionário e larval do ciclídeo acará-açu Astronotus ocellatus (AGASSIZ, 1831). Jaboticabal: Universidade Estadual Paulista, 64 p. Masters Dissertation.

PEREIRA, C.R., BARCELLOS, L.J.G., KREUTZ, L.C., QUEVEDO, R.M., RITTER, F. and SILVA, L.B., 2006. Embryonic and Larval Development of Jundiá (Rhamdia quelen, Quoy \& Gaimard, 1824, Pisces, Teleostei), a South American Catfish. Brazilian Journal of Biology = Revista Brasileira de Biologia, vol. 66, no. 4, pp. 1057-1063.http://dx.doi.org/10.1590/S1519-69842006000600013 PMid:17299942.

REYNALTÉ-TATAJE, D., ZANIBONI-FILHO, E. and ESQUIVEL, J.R., 2004. Embryonic and larvae development of piracanjuba, Brycon orbignyanus Valenciennes, 1849 (Pisces, Characidae). Acta Scientiarum: Biological Sciences, vol. 26, no. 1, pp. 67-71.
REYNALTÉ-TATAJE, D., ZANIBONI-FILHO, E. and MUELBERT, B., 2001. Stages of the embryonic development of the piavuçu Leporinus macrocephalus (Garavello \& Britski, 1988). Acta Scientiarum: Biological Sciences, vol. 23, no. 4, pp. 823-827.

ROMAGOSA, E., NARAHARA, M.Y. and FENERICH-VERANI, N., 2001. Stages of embryonic development of the "matrinxã", Brycon cephalus (Pisces, Characidae). Boletim do Instituto de Pesca, vol. 27, no. 1, pp. 27-32.

ROO, F.J., SOCORRO, J., IZQUIERDO, M.S., CABALLERO, M.J., HERNÁNDEZ-CRUZ, C.M. and FERNÁNDEZ-PALACIOS, H., 1999. Development of red porgy Pagrus pagrus visual system in relation with changes in the digestive tract and larval feeding habits. Aquacult., vol. 179, no. 1-4, pp. 499-512. http://dx.doi. org/10.1016/S0044-8486(99)00183-0.

SAMPAIO, K.H., 2006. Superficie ovocitária e desenvolvimento inicial de quatro espécies de peixes de interesse comercial da Bacia do Rio São Francisco. Belo Horizonte: Universidade Federal de Minas Gerais, 55 p. Masters Dissertation.

SANCHES, P.V., BAUMGARTNER, G., BIALETZKI, A., SUIBERTO, M.R., GOMES, F.D.C., NAKATANI, K. and BARBOSA, N.D.C., 2001. Caracterização do desenvolvimento inicial de Leporinus friderici (Osteichthyes, Anostomidae) da bacia do rio Paraná, Brasil. Acta Scientiarum: Biological Sciences, vol. 23 , no. 2 , pp. 383-389.

SHIELDS, R.J., BROWN, N.P. and BROMAGE, N.R., 1997. Blastomere morphology as a predictive measure of fish egg viabilility. Aquaculte, vol. 155, no. 1-4, pp. 1-2. http://dx.doi. org/10.1016/S0044-8486(97)00105-1.

SHIROTA, A., 1970. Studies on the mouth size of fish larvae. Bulletin of the Japanese Society of Scientific Fisheries, vol. 36, no. 4, pp. 353-368. http://dx.doi.org/10.2331/suisan.36.353.

SILVA, R.A.P.S., VILLACORTA-CORREA, M.A., BARCELOS, J.F.M. and ARAUJO, M.L.G., 2007. Caracterização histológica do estômago e intestino em larvas de matrinxã Brycon amazonicus (Characiformes- Characidae). In: Anais do XV Congresso Brasileiro de Engenharia de Pesca, 2007, Manaus, Brasil.

TREJO, A.B. and MARTÍNEZ, F., 1983. Reproducción inducida y levante del pie de cria de cachama Colossoma macropomum, Cuvier, 1818, em la estación Guanapito, Estado Guarico, Venezuela. Revista Veterinaria Venezolana, vol. 48, no. 276, pp. 17-24.

WOLPERT, L., JESSELL, T., LAWRENCE, P., MEYEROWITZ, E., ROBERTSON, E. and SMITH, J., 2000. Principios de biologia do desenvolvimento. 3th ed. Porto Alegre: Artes Médicas Sul. 576 p.

WOYNAROVICH, E. and HORVÁTH, L., 1983. A propagação artificial de peixes de águas tropicais: manual de extensão. Brasília: FAO/CODEVASF/CNPq.

ZANIBONI-FILHO, E., REYNALTE-TATAJE, D. and WEINGARTNER, M., 2006. Potencialidad del género Brycon en la piscicultura brasileña. Revista Colombiana de Ciencias Pecuarias, vol. 19, no. 2, pp. 233-240. 